\title{
The Effect of Organizational Culture and Compensation on Turnover Intention Mediated by Job Satisfaction of the Employees (A Case Study on Insurance companies in Jakarta)
}

\author{
Priscila Kristanti Putri ${ }^{1}$, Rina Anindita ${ }^{2}$ \\ Magister Management Esa Unggul University Jakarta ${ }^{1,2}$
}

\begin{abstract}
The purpose of this study is to analyze the effect of organizational culture and compensation on turnover intention mediated by employee job satisfaction on the employees of insurance companies in Jakarta. Turnover intention needs to be considered by management because it can interfere with the operation of the company. The higher the turnover, the higher the turnover intention of the employees. Organizational culture is a system of disseminating beliefs and values that develop within an organization and directing the behavior of its members. Compensation is the single largest operating cost that has a direct effect on employees to stay in their current organization. Job satisfaction is the emotional state of employees in looking at their job. The data were analyized using Structural Equation Modeling method. By using the object of research on temporary and permanent employees of insurance companies in Jakarta, there were 194 respondents as research sample. The results showed that organizational culture and compensation had positive effect on job satisfaction, so the high organizational culture and compensation could improve job satisfaction in the organization. Compensation had an effect on turnover intention. As well as job satisfaction could be able to mediate the relationship between organizational culture and compensation on turnover intention, as the higher the level of job satisfaction, the lower the turnover intention of the employees.
\end{abstract}

Keywords: Organizational Culture, Compensation, Job Satisfaction, and Turnover intention

\section{INTRODUCTION}

Organizational culture is a system of disseminating beliefs and values that develop within an organization and directing the behavior of its members. Compensation is the right tool for organizations to attract and retain their members, as it reflects organizational reward and is an indication of employee performance. Job satisfaction is the key to encourage the spirit, discipline, and performance of the employees so that the company's goals can be achieved. Turnover intention is the employee's desire to leave the company. Azam (2012) analyzed the effect of organizational culture on the level of job satisfaction of employees, especially for the organizations in Lahore, Pakistan. This study determined the relationship between organizational culture and job satisfaction, and the relative variance between types of culture and the level of job satisfaction. The results revealed that culture is an indicator that influences the level of employee job satisfaction. Medina (2012) explored the relationship between job satisfaction and turnover intention in of the attitude of the people of the United States. The results of the study showed that job satisfaction was inversely proportional to turnover intention, the relationship between job satisfaction and turnover intention. Another study conducted by Vveinhardt et al. (2014) in the Chemical sector, in the Karch - Pakistan region showed that the Supportive and Bureaucratic culture had a significant effect on employee commitment and job satisfaction while Innovative culture in companies in the Chemical sector did not have significant effect on employee job satisfaction and commitment. The results showed the effect of organizational culture on commitment and turnover intention. Kim (2016) examined the relationship between training in organizational culture and the effect of job satisfaction in the South Korean manufacturing industry that was implemented in 2013. The results of this analysis showed the significant relationship between training and job satisfaction, and between organizational culture and job satisfaction, and between training, organizational culture and job satisfaction. Yaseen et al. (2013) in Punjab and Idrus et al. (2016) in Kupang, NTT researching compensation against the influence of job satisfaction. The results of the study showed that compensation has an effect on job satisfaction in public servants, both directly and indirectly. Islamini and Mabaso (2017), investigated the effect of compensation, the benefits of job satisfaction among academic staff in Indonesia, and higher education institutions in the South Africa context. The results showed that there was positive and significant effect of compensation on job satisfaction. The study conducted by Yin-Fah (2010) discussed organizational commitment, job stress, job satisfaction, and turnover intention among private sector employees in Petaling. The results showed that there 


\section{International Advanced Research Journal in Science, Engineering and Technology}

Vol. 6, Issue 5, May 2019

was a significant negative relationship between organizational commitment and turnover intention. In addition, there were also positive relationship between job stress and turnover intention and negative relationship between job satisfaction and turnover intention. Dixit et al. (2012) analyzed the effect of compensation in terms of rewards and benefits and organizational fairness about turnover intention and the role of job satisfaction in terms of payment in the Indian Retail Industry. Based on the results of the study, it can be seen that organizational rewards and fairness in terms of distributive and procedural fairness have some effect on job satisfaction which in turn have some effect on and can be considered as one of the reasons for the high turnover intention. The study conducted by Weldeyohannes (2015) discussed the practice of compensation and turnover intentions of teachers in Tigray. The results showed that the perceived job satisfaction has an effect on turnover intention. Harder and Strong (2009) in Florida provided an overview of the causes of job dissatisfaction that force an employee to quit his/her current job and consider other job opportunities. The decision made by the agents to leave the organization can be affected by the level of job satisfaction and job dissatisfaction. Som and Albattat (2013) attempted to present the effect of demography, salaries and wages, and environmental organizations on employee job satisfaction in the Malaysian hospitality and tourism industries. The results showed that there is an effect of demography, salaries and wages, and environmental organizations on job satisfaction. Furthermore, the study conducted by Rizwan et al. (2014) on Bahawalpur's employees showed that job satisfaction, employee performance and exchange of leadership members had a direct negative effect on turnover intention. Shah and Jumani (2015) examined the relationship between job satisfaction and turnover intention of private high school teachers in Rawalpindi and Islamabad districts. This study concluded that there is a strong relationship between job satisfaction and turnover intention indicators among the private high school teachers.

\section{Organizational Culture}

Schein (2005) defines organizational culture as a pattern of basic assumptions found or developed by a group of people as they learn to solve problems, to adapt to the external environment and to integrate with the internal environment. Glaser et al. (1987) in Kreitner and Kinicki (2005) state that organizational culture is often described in the sense that it is shared collectively. The patterns of trust, symbols, rituals and myths develop over time and serve as the unifier of the organization. According to Robbins and Judge (2011), organizational culture is a system of shared meanings adopted by members that distinguish the organization from others. According to Robbins and Coulter (2010), organizational culture is a system that has values, principles, traditions, and ways of working adopted by the members of the organization. Furthermore, Buchanan (1974) in Vandenberg and Lance (2002) states that if employees feel to be bound to the values of the organization in the form of existing organizational culture and are happy at work, they will do their tasks and duties well and work sincerely, so that it is expected to reduce the effect on attendance, turnover, and work delays.

\section{Job Satisfaction}

The activities performed by human are diverse and one of the forms of all existing activities is work. Work means carrying out a task that ends up with a result that can be enjoyed by the related human. This is driven by human desire to meet his/her needs. According to Davis and Keith (1985), job satisfaction is a psychological atmosphere about feeling pleasant or unpleasant about their work. As quoted by Roshidi (1999), job satisfaction is a reference to an employee's effective orientation towards his/her role in the current position. A positive attitude toward work conception can be expressed as job satisfaction and a negative attitude toward work means dissatisfaction. This definition is supported by Smith and Kendall (1963), that job satisfaction is someone's feeling regarding his/her job. According to Hasibuan (2007), job satisfaction is a pleasant emotional attitude and loves to the job. This attitude is reflected by morale, discipline and performance in working. Job satisfaction is enjoyed inside, outside, and in combination between the inside and outside working.

\section{Compensation}

Compensation is an important factor that has an effect on how and why people work in an organization, not in the other organizations. Employers must be competitive enough with several types of compensation to employ, maintain and reward the performance of each individual in the organization. According to Hasibuan (2007), Compensation is the expenditure and costs of the company. According to Dessler et al. (1997), compensation is all forms of payroll or rewards for employees and arise from the staffing of Yani (2012). Meanwhile, according to Handoko (2001), compensation is everything that employees receive as compensation for their work. Thus, compensation is something received by employees in return for their work. In addition, compensation is an expense of the company in managing the organization. The provision of compensation has several objectives, including; (1) to meet the economic needs of employees or as an economic guarantee for employees; (2) encouraging employees to be better and more active; (3) Indicating that a company has a progress.

\section{Turnover Intention}

According to Mathias and Jackson (2001), turnover intention is a process where the workforce leaves the organization and some must replace. According to Harninda (1999) Turnover intention is basically the same as the desire to move 


\section{International Advanced Research Journal in Science, Engineering and Technology}

Vol. 6, Issue 5, May 2019

from one workplace to another. This opinion shows that turnover intention is a desire to move from one workplace to another, but has not realized the desire yet. Harnoto (2002) states that turnover intention is the level or intensity of the desire to leave the company, as there are many reasons cause turnover intention and one of them is the desire to get a better job. Thus, it can be concluded that turnover intention is the desire of the employees to leave the company.

\section{HYPOTHESIS DEVLOPMENT}

Organizational culture can provide firmness and reflect thespecifications an organization so different from otherorganizations. Azam (2012) analyzed the effect of organizational culture on the level of job satisfaction of employees, especially for the organizations in Lahore, Pakistan. This study determined the relationship between organizational culture and job satisfaction, and the relative variance between types of culture and the level of job satisfaction. The results revealed that culture is an indicator that influences the level of employee job satisfaction. Medina (2012) explored the relationship between job satisfaction and turnover intention in of the attitude of the people of the United States. The results of the study showed that job satisfaction was inversely proportional to turnover intention, the relationship between job satisfaction and turnover intention. Another study conducted by Vveinhardt et al. (2014) in the Chemical sector, in the Karch - Pakistan region showed that the Supportive and Bureaucratic culture had a significant effect on employee commitment and job satisfaction while Innovative culture in companies in the Chemical sector did not have significant effect on employee job satisfaction and commitment. The results showed the effect of organizational culture on commitment and turnover intention. Kim (2016) examined the relationship between training in organizational culture and the effect of job satisfaction in the South Korean manufacturing industry that was implemented in 2013. The results of this analysis showed the significant relationship between training and job satisfaction, and between organizational culture and job satisfaction, and between training, organizational culture and job satisfaction.

$\mathrm{H}_{1}$ : The good Organizational Culture can improve Job Satisfaction

The company must be competitive enough with some type ofcompensation for hiring,retain and reward performance against each individual in the Organization. The study conducted by Yaseen et al. (2013) in Punjab and Idrus et al. (2016) in Kupang, East Nusa Tenggara, was to find out the effect of compensation on job satisfaction. The results of the study showed that compensation has an effect on job satisfaction in public servants, both directly and indirectly. Islamini and Mabaso (2017), investigated the effect of compensation, the benefits of job satisfaction among academic staff in Indonesia, and higher education institutions in the South Africa context. The results showed that there was positive and significant effect of compensation on job satisfaction.

\section{$\mathrm{H}_{2}$ : The high compensation can improve Job Satisfaction}

Turnover Intention is the level or intensity of the desire to getout of the company, many of the reasons that cause the onset of this intentionand turnover among them is the desire to get a better job, this could be related to job satisfaction of the employees compensation or income of the company. The study conducted by Yin-Fah (2010) discussed organizational commitment, job stress, job satisfaction, and turnover intention among private sector employees in Petaling. The results showed that there was a significant negative relationship between organizational commitment and turnover intention. In addition, there were also positive relationship between job stress and turnover intention and negative relationship between job satisfaction and turnover intention. Dixit et al. (2012) analyzed the effect of compensation in terms of rewards and benefits and organizational fairness about turnover intention and the role of job satisfaction in terms of payment in the Indian Retail Industry. Based on the results of the study, it can be seen that organizational rewards and fairness in terms of distributive and procedural fairness have some effect on job satisfaction which in turn have some effect on and can be considered as one of the reasons for the high turnover intention. The study conducted by Weldeyohannes (2015) discussed the practice of compensation and turnover intentions of teachers in Tigray. The results showed that the perceived job satisfaction has an effect on turnover intention.

\section{$\mathrm{H}_{3}$ : The high Compensation can reduce the Turnover intention}

A positive attitude towards work in the conception of can beexpressed as

job satisfaction and negative attitude towardswork closely with dissatisfaction. Harder and Strong (2009) in Florida provided an overview of the causes of job dissatisfaction that force an employee to quit his/her current job and consider other job opportunities. The decision made by the agents to leave the organization can be affected by the level of job satisfaction and job dissatisfaction. Som and Albattat (2013) attempted to present the effect of demography, salaries and wages, and environmental organizations on employee job satisfaction in the Malaysian hospitality and tourism industries. The results showed that there is an effect of demography, salaries and wages, and environmental organizations on job satisfaction. Furthermore, the study conducted by Rizwan et al. (2014) on Bahawalpur's employees showed that job satisfaction, employee performance and exchange of leadership members had a direct negative effect on turnover intention. Shah and Jumani (2015) examined the relationship between job satisfaction and turnover 


\section{International Advanced Research Journal in Science, Engineering and Technology}

Vol. 6, Issue 5, May 2019

intention of private high school teachers in Rawalpindi and Islamabad districts. The results of the study, namely that job dissatisfaction that affects poor conditions, low responsibility, stress, and injustice between employees will help them to work.

\section{$\mathrm{H}_{4}$ : The high Job Satisfaction can reduce Turnover intention.}

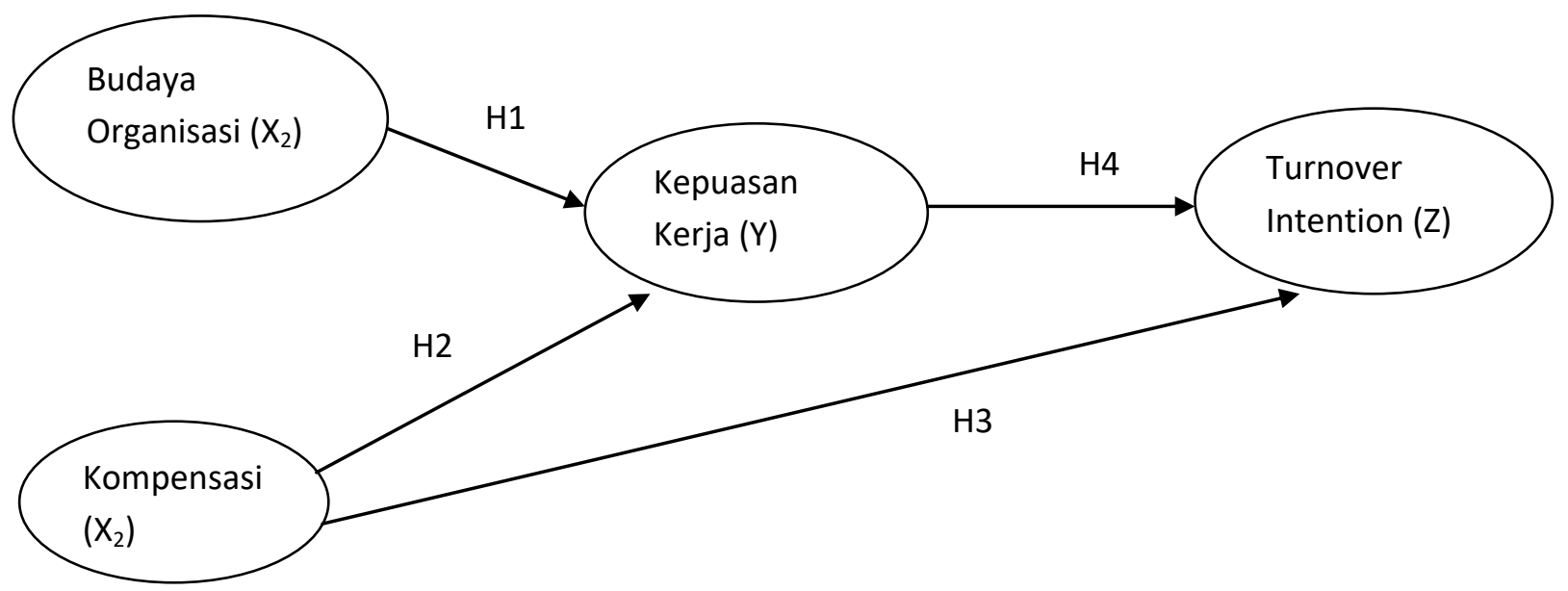

Figure 3.2 The Model of Conceptual Framework with Hypothesis

\section{METHODS OF THE RESEARCH}

This research was conducted on employees of insurance companies in Jakarta. There were several aspects studied, such as organizational culture, compensation, turnover intention, and job satisfaction. This research is categorized as quantitative descriptive research, a research on the data collected and expressed in the form of words arranged in sentences, for example, questions in the survey questionnaire. The research model was tested using Structural Equation Modeling (SEM) of LISREL software type where the sample is ranging from 150-400. In this study, there were 160 respondents used as the sample, so it was considered sufficient. If the sample is more than 400, the LISREL sample will be very sensitive, Hisyam (2008). LISREL is a software developed specifically to overcome SEM problems. According to Black et al. (2008), it is a must of having a number of sample of five times the number of questions analyzed. The guideline was 5-10 times the number of estimated parameters, while this study contained 35 operations of the indicator, then 35 X $5=175$ was considered sufficient, with a total of 35 questions, thus, the minimum number of samples needed was 25 respondents. The number of sample in this study was 194. Maximum Likelihood Estimation technique requires sample ranging from 100-200. Another opinion states that the Maximum Likelihood Estimation (ML) technique is effective for sample ranging from 150-400, EQ and Wijaya (2012).

\section{Measurement}

There were three independent variables in this study, namely organizational culture, compensation, and job satisfaction, and one dependent variable, namely turnover intention. The measurement of organizational culture was conducted using the theory of Macintosh and Doherty (2008), while the job satisfaction was measured by using the theory of Blau (1987) and Susskind et al. (2000). Then, compensation was measured by using the theory of Mondy and Noe (1993) and turnover intention was measured by using the theory of Mathis and Jackson (2006). This study used confirmatory factor analysis by testing the validity, which was conducted by looking at the Kaiser-Msyer-Olkin measure of sampling (KMO) and measures of sampling adequacy (MSA) values. The low KMO value shows that the factor analysis cannot be used, because the correlation between variable pairs cannot be explained by other variables. The factor analysis cannot be accepted or used if the KMO value is lower than 0,500, while the factor analysis can be accepted if the KMO value is higher than 0,500 . The KMO value was lower than 0,500 , so that the factor analysis was rejected and the validity of each questionnaire was tested by using Anti-Image Matrix test. The expected MSA (Measure of Sampling Adequancy) value is 0,500 minimum (Doll, et al., 1994). Organizational culture scale consisted of 16 questions, as there were 8 of 16 questionnaires were not received. The received questionnaires were BO6 (0,723), BO7 (0,740), BO9 $(0,705)$, BO10 (0,745), BO12 (0,794), BO14 (0,739), BO15 (7,27), BO16 (0,627). While the turnover intention scale consisted of 5 questionnaires and the results showed that all values were higher than 0,500 , so that all questionnaires were received. The reliability test with a Cronbach's alpha value $>0,5$ means reliable (Sugiyono, 2012), so that, it can be said that the indicators of all variables were reliable as a data collection tool in the study. 


\section{International Advanced Research Journal in Science, Engineering and Technology}

Vol. 6, Issue 5, May 2019

\section{RESULTS}

The analysis of all tests almost showed good fit, among others Chi Square, RMSEA, ECVI, AIC, CAIC and Fit Index. There was a poor fit result on Critical $\mathrm{N}$ and a marginal fit on Goodness of Fit. Then, this study resulted in a path diagram, as follow:

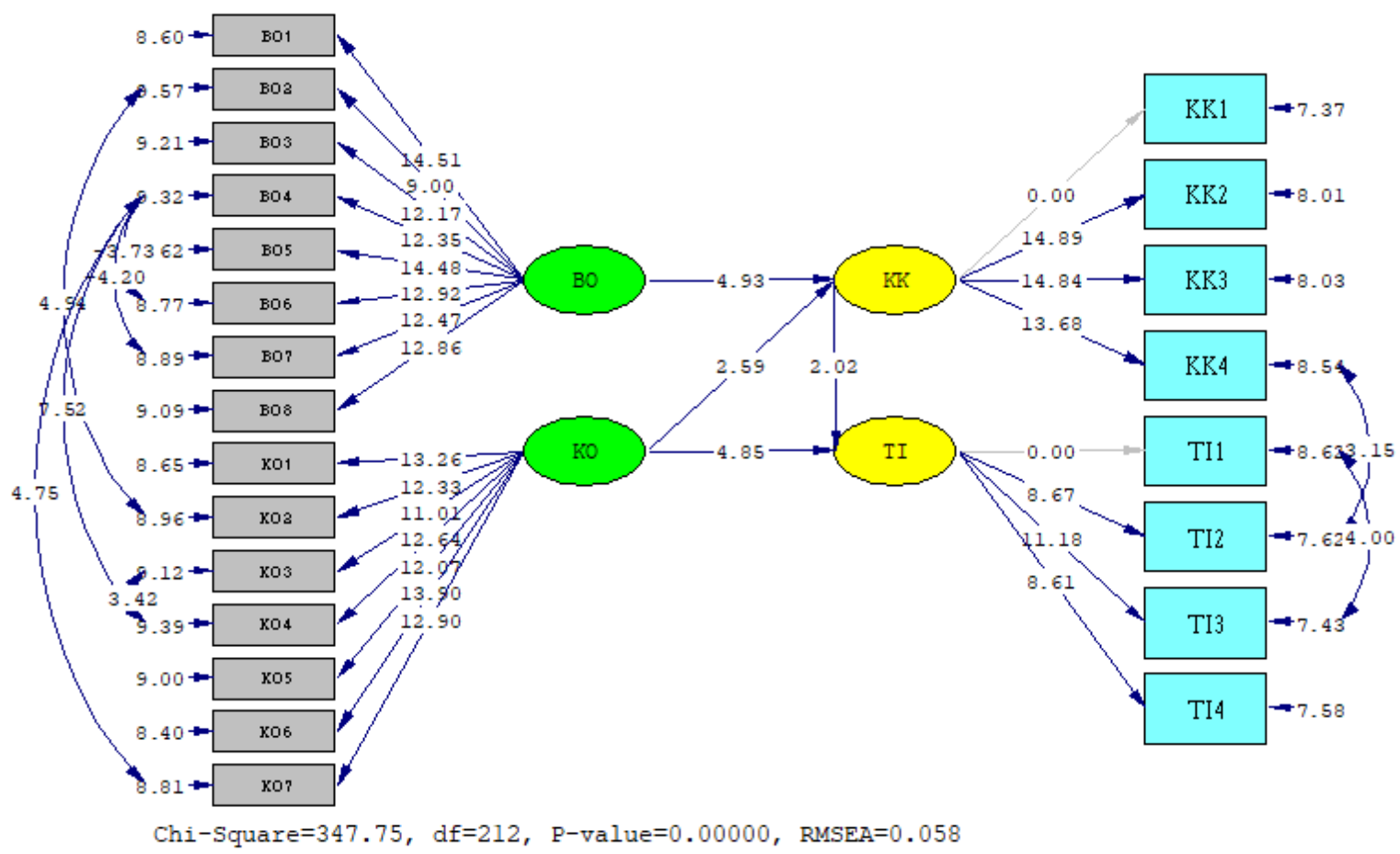

Figure 5.2: Path Diagram ( T Value )

Based on Figure 2, the Path Diagram T-Value is the hypothesis in this study, as shown in the table of hypothesis test below:

\begin{tabular}{|c|l|c|c|}
\hline Hypothesis & \multicolumn{1}{|c|}{ Hypothesis Statement } & T-Value & \multicolumn{1}{c|}{ Information } \\
\hline H1 & $\begin{array}{l}\text { The good Organizational Culture can } \\
\text { improve Job Satisfaction }\end{array}$ & 4,93 & The data support the Hypothesis \\
\hline H2 & $\begin{array}{l}\text { The high compensation can improve Job } \\
\text { Satisfaction }\end{array}$ & 2,59 & The data support the Hypothesis \\
\hline H3 & $\begin{array}{l}\text { The high Compensation can reduce the } \\
\text { Turnover intention }\end{array}$ & 4,85 & The data support the Hypothesis \\
\hline H4 & $\begin{array}{l}\text { The high Job Satisfaction can reduce } \\
\text { Turnover intention }\end{array}$ & 2,02 & The data support the Hypothesis \\
\hline
\end{tabular}

The path coefficient is 4.93. This influence is positive, meaning high organizational culture can increase job satisfaction. Based on these results it can be said that by building a good organizational culture has a significant role in increasing job satisfaction of insurance employees in the Jakarta. The path coefficient is 2.59. The influence is positive, meaning that high compensation can increase job satisfaction. In this study, high job satisfaction in employees indicates that employees are satisfied with the compensation provided by the company and ultimately the employee does not hesitate to remain in the company. 


\section{International Advanced Research Journal in Science, Engineering and Technology}

Vol. 6, Issue 5, May 2019

In this case, employee performance can be an assessment of the company, namely how operations can run well. The path coefficient is 4.85 . This influence is positive, meaning that high compensation can reduce Turnover Intention. Based on the results of this study it can be said that there is a high enough value on the role of compensation to turnover intention. Where high compensation provided by insurance companies in Jakarta can reduce turnover intention. Research shows that compensation for insurance companies in the Jakarta area can reduce turnover intention. The path coefficient is 2.02. This influence is positive, meaning that high job satisfaction can reduce Turnover Intention. Seeing the results of this study employee job satisfaction in insurance companies in Jakarta affect turnover intention. So the insurance company in Jakarta should be able to keep its employees from leaving the company

\section{DISCUSSION}

In the result of the first hypothesis (H1) test, it was found that Organizational Culture has a significant effect on Job Satisfaction. The result supports the studies conducted by Azam (2012), Medina (2012), Vveinhardt et al. (2014), and Kim (2016) where the results of these studies indicated that there is a significant effect of organizational culture on job satisfaction. Based on these results, it can be said that a good organizational culture plays a significant role in improving job satisfaction of insurance employees in Jakarta. It is very important to remember that with the incorporation of organizations with different work patterns must use one of the work patterns that have been implemented when joining them, as it will be more difficult with the feeling that the process that has been carried out for years by one organization is considered better than other organizational work patterns.

Increasing the role of organizational culture in insurance companies in Jakarta is by increasing or creating a sense of being accepted by the company environment where a person works. Increasing the sense of being accepted can be made by making the represented company able to tell the points of mistakes made by the employees and provide solutions by exemplifying and telling the good and right ways in doing something and also assigning tasks to employees according to their competence. In the result of the second hypothesis (H2) test, it was found that high compensation has a significant effect on job satisfaction. This result supports the studies conducted by Yaseen et al. (2013), Idrus et al. (2016), and Diamin and Mabaso (2017) where the results of these studies indicated that there is a significant effect of compensation on job satisfaction. The high job satisfaction in employees indicates that employees are satisfied with the compensation given by the company and, ultimately, they do not hesitate to stay in the company.

In this case, employee performance can be an assessment of the company, in terms of how the operations can run well. In the result of the third hypothesis (H3) test, it was found that compensation has a significant effect on turnover intention. This result supports the studies conducted by Yin Fah (2010), Dixit et. al (2012), and Weldeyohannes (2015), and where the results of these studies indicated that there is a significant effect of compensation on turnover intention. Based on the results, it can be said that there is a failry high value on the role of compensation on turnover intention in which the high compensation provided by insurance companies in Jakarta can reduce turnover intention. The study showed that compensation for insurance companies in Jakarta can reduce turnover intention. Compensation is variable, which became one of the important attention in this research. Both direct, indirect and non-financial compensation. In this study, insurance companies must be able to increase the provision of employee leave rights, and on how employees do not find difficulties in applying their leave rights every year and become satisfied with bonuses. Insurance companies should pay more attention to the bonus received by the employees.

In addition, to maintain incentives, travelling, pension benefits (adequate benefits for the pensioners), promotion opportunities, and recognition and rewards. Job satisfaction is a positive attitude of the employees towards the job that arises based on an assessment of the work situation. Job satisfaction is also an indication of someone's feelings towards their job. In this study, insurance companies in Jakarta are expected to be able to increase the satisfaction in the same job in terms of how insurance companies can motivate employees to do their job so as not to try to evaluate alternative job. In the result of the fourth hypothesis (H4) test, it was found that job satisfaction has a significant effect on turnover intention.

This result supports the studies conducted by Harder and Strong (2009), Som and Albattat (2013), Rizwan et al. (2014), and Shah and Jumani (2015) where these studies indicated that there is a significant effect of job satisfaction and turnover intention. By looking at the results of this study that job satisfaction in insurance companies in Jakarta has an effect on turnover intention, the insurance companies in Jakarta should be able to keep their employees from leaving, especially for the employees who give great contribution to the company. In order to create a mutually beneficial relationship, insurance companies in Jakarta try to create a conducive working atmosphere. Interview conducted to the employees who have turnover intention is a great way to explore the reasons that make them decide to quit their jobs. The next step is to implement new procedures or policies to prevent turnover intention in insurance companies in Jakarta. 


\section{International Advanced Research Journal in Science, Engineering and Technology}

Vol. 6, Issue 5, May 2019

\section{CONCLUSIONS}

\section{Conclusion}

There are some conclusions based on the results of the study, first, building a good organizational culture will improve the job satisfaction of insurance employees in Jakarta (the first hypothesis is supported), so that building the organizational culture at this time in an insurance companies is to create a new work pattern that will be implemented, so that it does not favor one and does not become an overlap between previous work patterns. With the existence of a work pattern certainly makes the work clearer than who will do the work and also limit the responsibility. Building the top--down communication also makes the organizational culture of the insurance companies in Jakarta better, so that everything that will be created will improve job satisfaction of all employees.

\section{Limitations of the Research}

There were several limitations in this study that can be considered for future research. This study used a questionnaire as a measurement tool because of the need to save time and energy. However, the questionnaire had several limitations, such as biases in responding questions and answers from respondents. There was a possibility that the respondent does not fill in properly or just fill in based on the expected ideal conditions, not the actual conditions. This can cause the measurement does not describe the variables significantly. In addition, the limited number of samples, as much as 194, and the number of variables, as many as four variables, and the number of analyzes caused the study could not explore deeper about other factors that have effect on turnover intention.

\section{Suggestions for Future Research}

Based on the above results, there are some suggestions for the company, for example, by developing performance management and implementing Key Performace Indicator (KPI). KPI is expected to be able to apply professional career levels, and the period of salary increases. KPI is able to make employees more motivated to develop and is expected to improve job satisfaction with the organization. With this calculation system, it will certainly make the company easier in setting and finding out its progress, since KPI helps in the process of making employee performance assessment, selecting employees for promotion in certain career levels, and even determining the portion and period of salary increase. Performance management should be considered by the company, namely how companies can apply performance management as a basis for educating and developing the talent of its employees, so that employees can perceive the opportunity given to pursue a career and reduce the turnover intention.

\section{REFERENCES}

[1]. Agung, A.M., Lilik, (2007). Dari Budaya Perusahaan ke Budaya Kerja. Corporate Culture, Challenge to Excellence, Jakarta: PT Elex Media. Komputindo

[2]. Ahmad, M. A. Roshidi. (1999). Pengaruh Iklim Organisasi ke Atas Kepuasan KerjaGuru-Guru Sekolah Menengah Kajian Kes di Daerah Padang Terap, Kedah, Tesis Sarjana Sains Fakulti Sains Kognitif dan Pembangunan Manusia, Universiti Malaysia Sarawak, (http://www.Webcastmy.Com)

[3]. Azam, Shamaila Gull and Fariha (2012). Impact of Organizational Culture Type on JobSatisfaction Level of Employees' in Different Organizations of Lahore, Pakistan. International Journal of Academic Research in Business and Social Sciences. Vol. 2 , No. 12

[4]. Cameron, K.S, Freeman and Mishra, A, (1991), "Best Practiccs in White Collar.Downsizing: Managing Contradictions," Academy of Management. Executive, 5 (3): 57-73. Clisson, Charles and Durick, Mark, (1988),"Predictors of Job Satisfaction and. Organization Coimnitment in HumanService Organizations," Coriiell

[5]. Davis, Keith dan John W. Newstrom. (1985). Perilaku Dalam Organisasi. Jakarta: Erlangga

[6]. Dlamini dan Mabaso (2017), "Research Article Impact of Compensation and Benefits on Job Satisfaction" Research Journal of Business Management, ISSN 1819-1932

[7]. Dixit, V., \& Bhati, M. (2012). A Study about Employee Commitment and its impact on Sustained Productivity in Indian Auto-Component Industry. European Journal of Business and Social Sciences, 1(6), 34-51.

[8]. Edgar H. Schein (2005), Perilaku dan manajemen organisasi, edisi 7, jilid 1, Erlangga

[9]. Glaser dalam Kreitner, Robert Kreitner, Angelo (2005). Perilaku Organisasi(Organizational Behavior) . Terjemahan: Erly Suandy Jakarta: SalembaEmpat

[10]. Handoko, T. H. (2001), Manajemen Personalia dan Sumber Daya Manusia. Yogyakarta: BPFE

[11]. Harder, Robert Strong, Amy (2009). Implications of Maintenance and Motivation Factors on Extension Agent Turnover. Journal of Extension.Vol 47, No. 1

[12]. Harnoto, (2002). Manajemen Sumber Daya Manusia, Edisi Kedua, PT. Prehallindo, Jakarta

[13]. Hasibuan SP. Malayu, (2007), Manajemen Sumber Daya Manusia, Edisi Revisi, BumiAksara, Jakarta.

[14]. Herzberg .F. Work and the Nature of Man. London : Granada Publishing Limited

[15]. Hollingsworth,(1978). Hofmann,Thomas G."Priming the Pump for Outside Fundraising Nursing Home 41 (Aug. 1992): 26-27, A.T. "Creativity in Nonprofit Organization"

[16]. Idrus, Rahmat Laan , Muhammad Yunus Zain , Mahlia Muis, Muhammad Taba.(2016). The Effect Of Composation And Employee Development On The JobSatisfaction And Employee Performance. International Journal Of ResearchIn Social Sciences. Vol. 6, No.5

[17]. Kenneth, N.Wexley, dan Gary, A. Yuki. (2003). Perilaku Organisasi dan Psikologi Personalia. Jakarta: PT. Rineka Cipta

[18]. Kim, H., Damhorst, M.L., \& Lee, K. (2002). Apparel involvement and advertisement processing. Journal of Fashion Marketing and Management, Vol 6, No 3.

[19]. Kotter, John P., dan James L. Heskett, (2006), Budaya Korporat dan Kinerja. Terjemahan: Susi Diah Hardaniati \& Uyung Sulaksana. 


\section{International Advanced Research Journal in Science, Engineering and Technology}

Vol. 6, Issue 5, May 2019

[20]. Kreitner, Robert dan Kinicki, Angelo,(2005). Perilaku Organisasi, buku 1 dan 2, Jakarta : Salemba Empat.

[21]. MacIntosh and Doherty (2008). Cross-sectoral Variation in Organizational Culture in the Fitness Industry. Journal European Sport Management Quarterly. Vol 6No. 4, 445-446 2010

[22]. Mangkunegara, AA. Anwar Prabu, (2000). Manajemen Sumber Daya Manusia Perusahaan. Bandung : PT Remaja Rosdakarya

[23]. Martoyo Susilo, (2000). Manajemen Sumber Daya Manusia (Edisi 4), BPFE,Yogyakarta

[24]. Mathis, R.L. and J.H. Jackson. (2006). Human Resource Management: Manajemen Sumber Daya Manusia. Terjemahan Dian Angelia. Jakarta: Salemba Empat.

[25]. Medina, Elizabeth (2012). Job Satisfaction and Employee Turnover intention: What does Organizational Culture Have To Do With It? Columbia University Masters of Arts Fall 2012

[26]. Mowday, R. T., Steers, R. M., \& Porter, L. W. (1979). The measurement of Organizational commitment. Journal of Vocational Behavior, 14 (2),. 224, 247. Muhidin, S. A. (2010)

[27]. Robbins, SP dan Coulter, Marry (2010). Manajemen (edisi kesepuluh).Terjemahan: Bob Sabran, Wibi Wardani. Ed 10, Cet 13-Jakarta: Erlangga

[28]. Robbins, SP dan Judge, (2011). Perilaku Organisasi, Salemba empat, Jakarta

[29]. Robbins, Stephen P \& Judge, Timothy A. (2013).Organizational Behavior. Edition. 15. NewJersey: Pearson Education

[30]. Rizwan, Muhammad (2014). The relationship of Turnover intention with job satisfaction, job performance, Leader member exchange, Emotional intelligence and organizational commitment. International Journal of Learning and Development, Vol. 4, No. 2

[31]. Schein, E. H. (2008). Organizational Culture and Leadership. San Francisco: Jossey-Bass

[32]. Som, Ahmad Rasmi Suleiman AlBattat dan Ahmad Puad Mat (2013). Employee Dissatisfaction and Turnover Crises in the Malaysian Hospitality Industry. International Journal of Business and Management; Vol. 8, No. 5

[33]. Shah, Nazir Haider dan Jumani, Dr. Nabi Bux. (2015) Relationship of Job Satisfaction and Turnover intention of Private Secondary School Teachers. Mediterranean Journal of Social Sciences; Vol 6 No 4 S2

[34]. Simamora, Henry. (2006). Manajemen Sumber Daya Manusia, Edisi 2, STIE YKPN.Yogyakarta

[35]. Smith, P.C \& Kendall, L.M. (1963). Re translation of expectations: An approach toThe construction of unambiguous anchors to rating scales. Journal of AppliedPsychology, 47, 149-155

[36]. Sugiyono. (2004). Metode Penelitian Bisnis. Cetakan Kedua. Bandung:CV Alfabeta

[37]. Supranto, J.,(1992). Statistika dan Sistem Informasi Untuk Pimpinan, Penerbit Erlangga, Jakarta

[38]. Vandenberg, R. J., dan Lance, C. E. (2002). A review and synthesis of the Measurement invariance literature: Suggestions, practices, and recommendations for organizational research. Journal OrganizationalResearch Methods, Vol.3 No.9A.

[39]. Vveinhardt, Huma Abid Alvi, Mehmood Hanif, Muhammad Shahnawaz Adil RizwanRaheem Ahmed, Ph.D, Jolita, Ph.D.(2014).Impact of Organizational Culture on Organizational Commitment and Job Satisfaction. European Journal of Business and Management. Vol.6, No.27

[40]. Weldeyohannes, Gebremedhin. (2015). Compensation Practice and Teachers Turnover mIntention in Tigray. International Journal of Science and Research (IJSR). Volume 5 Issue 9

[41]. Wilbur, Schramm. (1985). The Process and Effect of Mass Communication. New York: University Of Illinois Press.

[42]. Yaseen, Ayesha.(2013). Effect of Compensation Factors on Employee Satisfaction- A Study of Doctores Dissatisfaction in Punjab. International Journal of Human Resource Studies.Vol. 3, No. 1.

[43]. Riswinandi (2010). Premi Asuransi Umum, April 2018,

[44]. http://keuangan.kontan.co.id/news/tahun-2018-ini-bisnis-jagoan-asuransi-umum 